\title{
Conservation of Zino's petrel Pterodroma madeira in the archipelago of Madeira
}

\author{
Francis Zino, Paulo Oliveira, Susan King, Alan Buckle, Manuel Biscoito, \\ $\mathrm{H}$. Costa Neves and Amilcar Vasconcelos
}

\begin{abstract}
Birds restricted to islands are susceptible to extinction, and burrow or ground-nesting birds are particularly vulnerable to introduced mammalian predators. Human intervention has also played a vital part. Birds have been used as a source of food, and in more recent times the rarer species have suffered from specimen and egg collection. The island of Madeira and its resident species, which include the endemic Zino's petrel or Madeira freira Pterodroma madeira, are no exception. From subfossil evidence, this bird was once abundant. It was first recorded in 1903, and was already limited to the high central mountain massif of Madeira. By the middle of the century it was considered extinct, but a relict population was rediscovered in 1969. By 1985, all known breeding attempts were disrupted by
\end{abstract}

introduced rats, to the extent that no young fledged. In 1986 the Freira Conservation Project was founded with the aim of increasing the population of Zino's petrel, by controlling rats and human interference, the principal perceived threats to the species. This control was extended to cats after the disaster of 1991, in which a cat(s) managed to get onto one of the breeding ledges and kill 10 adult birds. The results of these efforts have been positive and the small colony is making a slow, but steady recovery. To maintain this success, a conservation strategy for the future is suggested.

Keywords conservation, control, introduced species, Zino's petrel.

The present estimate for the breeding population of Zino's petrel is between 30 and 40 breeding pairs, with a breeding area restricted to the central mountains of Madeira (Zino \& Zino, 1986; Zino \& Biscoito, 1994; Zino et al., 1994). This gadfly petrel is a colonial species and, in the prebreeding season, carries out nocturnal flights above the nesting grounds during which it emits characteristic flight calls. Breeding occurs between March and October in burrows on cliff ledges where the vegetation is unaffected by grazing. Currently, five breeding ledges are known. The species' present conservation status is attributed to predation by introduced mammals, namely black rats Rattus rattus and feral cats Felis catus and the loss of habitat mostly as a result of overgrazing (Zino et al., 1996).

Zino's petrel was first recorded in Madeira in 1903 (Schmitz, 1905). At the time it was thought to be Fea's petrel Pterodroma (Oestrelata) feae, a species described from the Cape Verde Islands (Salvadori, 1899) that also breeds on the island of Bugio (Desertas), neighbouring Madeira. It is of interest to note that there are two skins of Pterodroma feae at the Cambridge Museum, collected by Frere off Madeira as early as 1853 , which remain undescribed. In 1934, Mathews suggested that the Pterodromas of Madeira and Bugio be considered as subspecies of Pterodroma mollis and be called P. m. madeira and P. $m$. deserta, respectively (Mathews, 1934a,b). Twenty years later, Bourne (1955) speculated that 


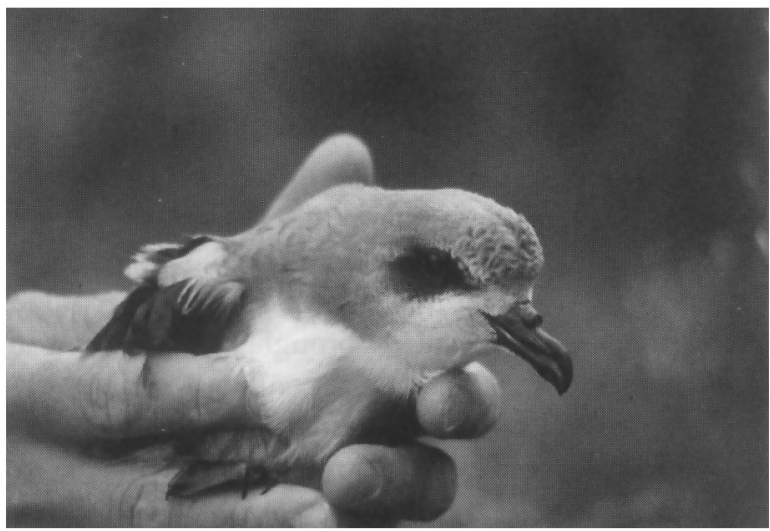

Plate 1 Zino's petrel Pterodroma madeira showing its distinctive black eye mark (Francis Zino).

$P . m$. deserta should be treated as a distinct species, but had difficulty in accepting that $P$. $m$. madeira, should also be considered as such (Bourne, 1957). In 1975, P.A. Zino considered the bird a distinct species (letter to W.B. King). Bourne (1983) formally proposed the separation of the subspecies into the following species: $P$. madeira, endemic to Madeira, P. feae, restricted to Bugio and the Cape Verde Islands; and $P$. mollis, of the Southern Ocean. Imber (1985) and Warham (1990) later confirmed this status. Recent DNA studies on blood samples from Zino's petrel and Fea's petrel confirm that they are distinct species (Nunn \& Zino).

At the time of the discovery of Madeira in 1419, Zino's petrel was probably common. There is subfossil evidence of its existence at various sites in Madeira as well as on the neighbouring island of Porto Santo ( $\mathrm{H}$. Pieper in a letter to P.A. Zino). However, by the mid-1960s, it was thought to be extinct. After years of searching, the petrel was rediscovered in 1969 in the central massif of Madeira by local ornithologist P.A. Zino. In the same year, collectors removed eight adult birds and seven eggs from the breeding ledges. As a result of the intervention of P.A. Zino, five of the birds were recovered alive and released. As a result, monitoring began on a very low key, to avoid the attention of collectors. However, the population was in decline and by 1985 no young fledged. This was attributed mainly to the activities of mammalian predators because eggs and chicks predated by rats were found on the ledges.

Investigations in 1985 and 1986 confirmed that rats were extremely active on the breeding ledges and evidence of predation on eggs and juveniles was found (Zino \& Zino, 1986). In 1991 cats were also noted to have predated adult birds; 10 birds from one breeding ledge were killed in this way (Zino, 1992).

In 1986 the Freira Conservation Project was launched with the objectives of monitoring the population size and productivity of Zino's petrel, controlling mammalian predators around the breeding ledges, and mitigating habitat degradation caused by sheep and goats in the area.

The Central Mountain Massif of Madeira, especially the area known as Montado do Areeiro, a designated Special Protected Area (SPA) by virtue of being the only known breeding area of Zino's petrel, contains some unique habitat with high conservation value (Plate 2 ). The site contains some of the best high altitude flora of Madeira, with approximately 33 endemic species from a total of 77 recorded plants (42 per cent). In areas which are not grazed, such as the breeding ledges, 75 per cent of the plant species are endemic (C.M. King, unpublished data). Some are classified as 'species in need of strict protection' under European law, e.g. Argyranthenum pinnatifidum, Berberis madeirensis and Viola paradoxa (EU Habitats Directive, 92/43/CEE). The flora is also very important for water catchment; droplets precipitate out of the mist on contact with foliage, then drip onto the ground. This water eventually finds its way to the levadas (i.e. narrow channels cut into the side of the mountains for the distribution of water into the towns for irrigation and drinking supplies) and is channelled to points of vantage for distribution. The area holds at least 14 species of land molluscs, nine of which are endemic (64 per cent) (C. Abreu, pers. comm.). The arthropod fauna of the area is poorly known, but data available indicate a high degree of endemism, especially in the millipedes, arachnids and some insect orders such as Coleoptera, Lepidoptera and Dermaptera (M. Biscoito \& F. Zino, unpublished). Amongst the more obvious insects, three endemic butterflies can be seen, the Madeiran speckled wood Pararge xiphia, the Madeiran Cleopatra Gonepteryx cleobule maderensis and the Madeira southern grayling Hipparchia aristaeus maderensis. Among the vertebrate fauna to be seen in the area, the

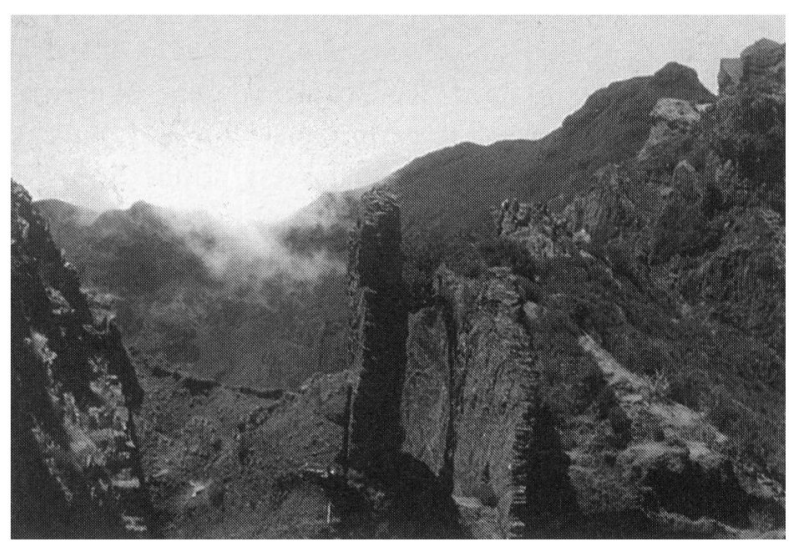

Plate 2 The Central Mountain Massif (Francis Zino). 
Madeiran lizard, Podarcis dugesii and the Madeiran bat Pipistrellus maderensis are both endemic.

This paper provides an overview of the work carried out by the Freira Conservation Project over the last 15 years. It also gives some information on the habitat in which these birds breed and the importance of its conservation. This habitat, the High Altitude Mountain Reserve, is an ecosystem in itself and Zino's petrel is just one of the many endemics that depend on it for survival.

\section{Methods}

\section{Population monitoring}

As a result of the inaccessible nature of the terrain in which the petrels breed, it was impossible to carry out systematic searches. Nesting areas were, therefore, located early in the breeding season by listening for the characteristic petrel vocalizations. Ledges with the appropriate characteristics, near where petrels were heard calling, were then accessed with ropes and searched for active burrows. This was done between April and June when the birds are more vocal and the active nests more conspicuous. Of the five known breeding ledges (Main Ledge, Small Ledge, 1987 Ledge, Spanish Ledge and 'Manga dos Vómitos' Ledge), the Main Ledge has been visited every year since 1985 . There have been regular searches of the other ledges since 1997.

Visits to the ledges were made once at the start of the breeding season, in the first two weeks of April, when burrows were in preparation, and then at least once more before the young fledged at the beginning of October. The nests that were easier to reach were visited more often. Productivity was calculated as the number of young fledged in relation to the number of active nests. In the past, data were affected by 'search effort' because some ledges, which were difficult to reach, were not visited every year. The 'search effort' was totally dependent on the availability of expert climbers.

Birds were ringed so that additional information could be gathered about the biology and ecology of Zino's petrel. Adult birds were captured in nest burrows before laying, during the early April visit and, later in the season, by mist netting. Removing adults from the nest in early April, which was some 6 weeks before laying started, in no way affected breeding success. All birds that were handled at this stage of the breeding cycle bred successfully. Juveniles were ringed before fledging.

\section{Rat control}

Black Rattus rattus were introduced into Madeira, probably in the early times of human settlement, some
500 years ago. In 1986, a preliminary study of rats in the petrels' main breeding area was carried out (Buckle \& Zino, 1989). As a result, special bait boxes were designed for rat control (Buckle \& Swash, 1987). The boxes were constructed locally from wood in such a way as to prevent entry of non-target species. A cordon of 65 of these boxes was deployed around the colony and further boxes were placed on the breeding ledges (Plate 3). They were baited throughout the year with the rodenticide $\mathrm{KLERAT}^{\mathrm{TM}}$ that contains 0.005 per cent brodifacoum in wax block formulation. The rodenticide was threaded onto a cord to prevent removal and suspended within the box over a baffle, so that broken bits of bait would not be dispersed outside the box, thus avoiding any possibility of primary poisoning, or of the poison infiltrating into the ground and thus into the water systems. Rats show a clear preference for brodifacoum on a grain base when it is compresed into pellets rather than when it is embedded in paraffin wax blocks (Aranda et al., 1992). Wax blocks, however, give a higher degree of protection against humidity and weathering (Moors et al., 1992; Taylor \& Thomas, 1993) and make it possible to determine, based on the tooth marks, whether bait consumption is by rat or mouse.

In order to monitor rodent activity and improve the control programme, the 65 boxes in the cordon have been checked weekly since February 1989. At each visit, the percentage of bait removed by rat or mouse was estimated within one of five classes, and chewed or damaged blocks were replaced. These data have been used to prepare an index of bait uptake for the years 1989-97. Preliminary analyses have been made to investigate bait uptake in relation to seasonal variations in temperature and rainfall. The uptake at individual boxes has been used to study the effectiveness of box position in relation to surrounding vegetation height, type and percentage cover, as well as altitude, general aspect and distance from the nearest neighbouring bait box.

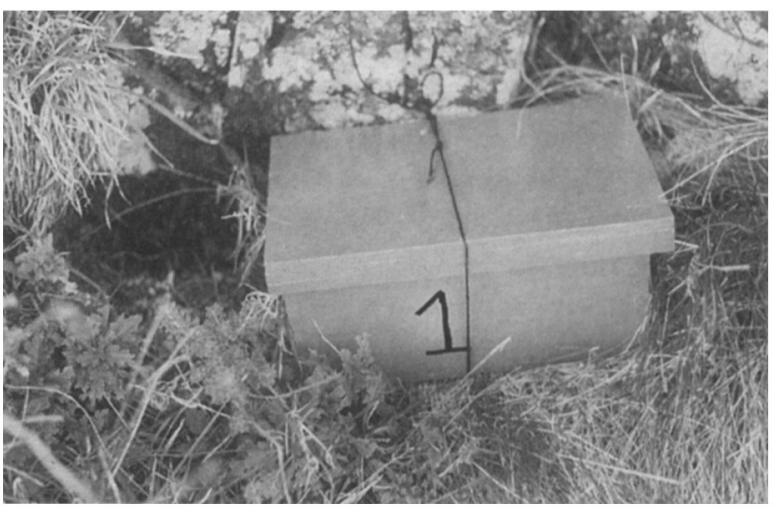

Plate 3 Rat bait box in position on a ledge (Francis Zino). 


\section{Cat control}

In 1991, following the killing by cats of 10 petrels on the 1987 Ledge, eight live cat traps (cage) were placed around the breeding grounds. This number has been gradually increased to the current 17 traps. Captured cats are removed from the area. The absolute number of cats caught measures cat activity in the area.

\section{Results}

\section{Population monitoring}

The five known breeding ledges comprised a maximum of 39 nests, not all of which were occupied in any one year. Nest productivity since 1986 is shown in Table 1.

Initial efforts on the part of the Freira Conservation Project were slow to produce a response in productivity, but in 1987 one bird was fledged. Productivity increased until 1993, then remained stable until 1995, declined from 1996 to 98 , and showed a marked upturn in 1999 and 2000.

Since 1986, 111 petrels have been ringed: 52 adults and 59 chicks. Five birds have been recaptured; four of which were ringed as adults and one as a juvenile. The juvenile was originally ringed in 1989 and was recaptured after 5 years, in July 1994, as a prebreeder. Of the four ringed as adults, two have been recaptured three times. Two birds have been recaptured on the Main Ledge as breeders; of these, one was originally ringed on the ledge, having been taken out of the burrow late in the season when we were checking the chicks. Rats had eaten the chick from this nest. This adult has been caught in the same burrow on two further occasions. The second bird was caught in nets and then again in a burrow on the Main Ledge 5 years later. The Main Ledge is some $500 \mathrm{~m}$ from the site where the nets were normally set. Almost all the birds caught in nets were considered prebreeders by virtue of the state of their brood patch.

Over the years, 14 adult birds have been found dead. In 1991, 10 were predated in a single incident by cat(s) (Zino, 1992). Since then three isolated adult birds have been found dead: one on the Main Ledge, probably because of natural causes; one below the Main Ledge; and two, partially eaten by cats, in the area around the breeding ledges. Whether cats actually killed the petrels or were scavenging on their remains was not clear. Only one of these 14 birds was ringed, but then not all the legs were found. In October 2000 a ringed bird was found, decomposing below the Main Ledge. From the ring we know it to have been a breeder on the Main Ledge, but the cause of death remains unknown. Cat scats with white feathers in them, almost certainly from a petrel, have also been found without evidence of a 'body'. This strongly indicates that not all birds predated by cats have been found. A number of chicks have been found outside their nest eaten by rats (Zino, 1991), but some have also been found dead outside their nest for no obvious reason, which may indicate the loss of a parent or failure of food supply.

\section{Rat control}

Annual rodenticide uptake, calculated from weekly records and converted to an index, is shown for the years 1989-97 in Fig. 1. Analysis of data is very labour intensive and is carried out every 3 years.

If bait uptake is taken as a circumstantial indicator of rat activity then, between 1989 and 1997, there was no correlation between rat activity and Zino's petrel productivity (Pearson $r=-0.258 ; R^{2}=6.6$ per cent, $P>0.5=0.503$ N.S.). Data from 1986 to 1988 were not considered because they were collected in a nonstandardized format.
Table 1 Results of nesting and breeding success of Zino's petrel. This table gives the number of nesting pairs on the Ledges, the number of eggs laid, chicks fledged and productivity, from 1986 to 2000 .

\begin{tabular}{lllllll}
\hline Year & $\begin{array}{l}\text { Pairs } \\
\text { (Main ledge) }\end{array}$ & $\begin{array}{l}\text { Pairs } \\
\text { (Other ledges) }\end{array}$ & $\begin{array}{l}\text { Pairs } \\
\text { (Total) }\end{array}$ & $\begin{array}{l}\text { Total No. } \\
\text { of eggs laid }\end{array}$ & $\begin{array}{l}\text { Chicks } \\
\text { fledged }\end{array}$ & $\begin{array}{l}\text { Productivity } \\
(n)\end{array}$ \\
\hline 1986 & 6 & - & 6 & 6 & 0 & 0.00 \\
1987 & 6 & 6 & 12 & 12 & 1 & 0.08 \\
1988 & 6 & 6 & 12 & 12 & 0 & 0.00 \\
1989 & 9 & - & 9 & 8 & 2 & 0.25 \\
1990 & 8 & - & 8 & 5 & 4 & 0.80 \\
1991 & 7 & - & 7 & 7 & 4 & 0.57 \\
1992 & 12 & - & 12 & 12 & 4 & 0.33 \\
1993 & 12 & - & 12 & 12 & 8 & 0.67 \\
1994 & 11 & 2 & 13 & 9 & 5 & 0.56 \\
1995 & 8 & - & 8 & 8 & 4 & 0.50 \\
1996 & 10 & - & 10 & 7 & 3 & 0.43 \\
1997 & 10 & 10 & 20 & 16 & 5 & 0.31 \\
1998 & 12 & 7 & 19 & 17 & 4 & 0.24 \\
1999 & 13 & 10 & 23 & 23 & 15 & 0.65 \\
2000 & 16 & 13 & 29 & 29 & 16 & 0.55 \\
\hline
\end{tabular}




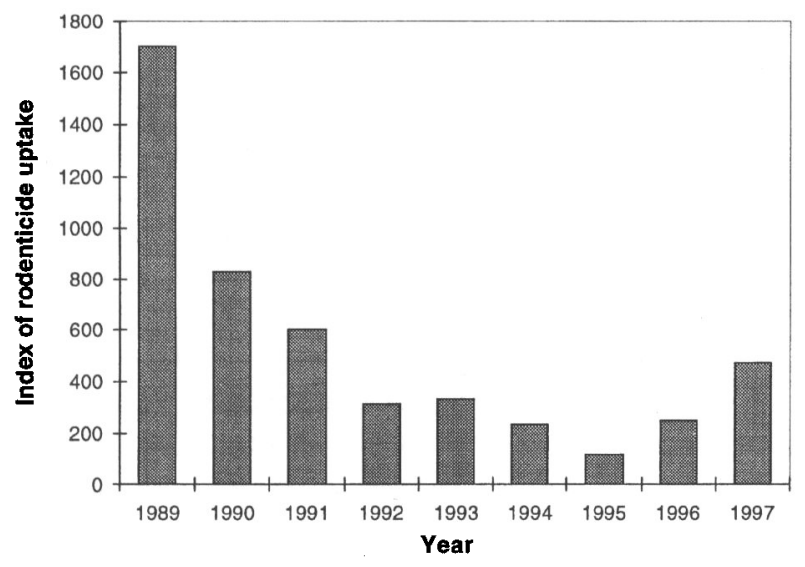

Fig. 1 Evolution of rat activity for 1989-97, calculated from annual rodenticide uptake.

The percentage of total annual bait uptake occurring in each month, averaged between years, is shown in relation to rainfall in Fig. 2.

October normally represented the month of maximum activity, but this varied annually by one month in either direction. Seasonal increase in rat activity between July and October was best predicted by the increase in daily maximum rainfall $\left(R^{2}(\mathrm{adj})=86.5\right.$ per cent, $P<0.05$, $P=0.046)$.

Rodent activity at individual boxes varied widely from year to year and within the same year. One group of boxes with consistently high levels of activity was situated below the main breeding cliff. Single factor regression analysis, however, revealed no significant associations between bait uptake and any of the physical or vegetation characteristics measured.

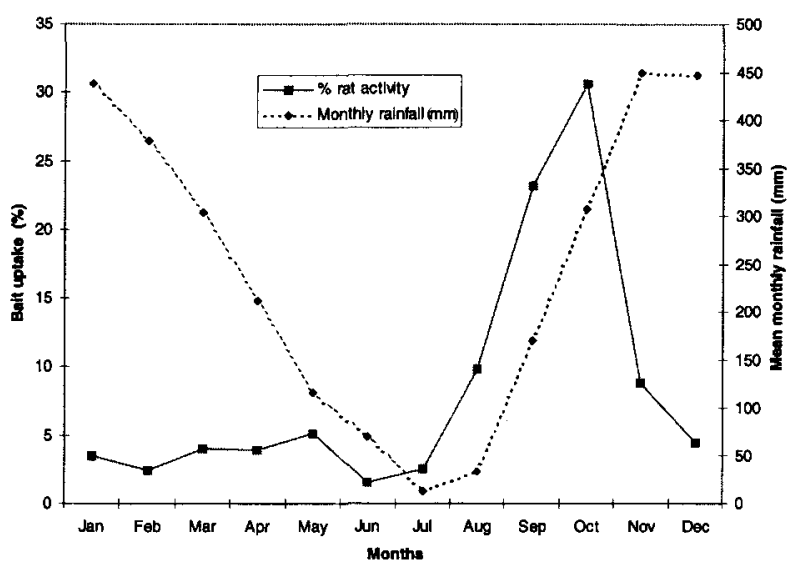

Fig. 2 Monthly rat activity in relation to rainfall. Percentage of total annual bait uptake occurring in each month, averaged between years.

\section{Cat control}

Since 1991, 45 cats have been captured; with an average of five cats caught every year since 1994 , and a maximum of 10 in 1997. With lack of staff and most of the human input designated to the petrels themselves, we have no further information on the cats (e.g. age and sex).

\section{Discussion}

\section{Population monitoring}

The five known nest ledges are unlikely to represent the total number of breeding sites. Location of new colonies is labour intensive, but may be possible with increased staffing and finance.

The initial rise in Zino's petrel productivity since 1989 is attributed to predator control measures put in place by the Freira Conservation Project. Improvements in productivity have been achieved in gadfly petrel colonies elsewhere when rats have been controlled (e.g. Coulter et al., 1982; Cruz \& Cruz, 1987). For the closely related cahow Pterodroma cahow, productivity above 0.4 chicks/pair is required to maintain a stable population (N. Ratcliffe \& D. Wingate, in prep.). The productivity of Zino's petrels has been above this putative threshold in eight of the 15 years of study. From 1996 to 1998, however, it declined below this level, for an unknown reason, only to rise again in 1999 and 2000. For other seabird species, variation in food supply has been shown to be a contributory factor to decline (cf. Monaghan, 1995). It is not possible to test this hypothesis in this case because little is known of the diet of Zino's petrel. Present knowledge is restricted to observations and samples collected when birds occasionally vomit during ringing. Regurgitations have contained beaks and lenses of cephalopods, bones of myctophid fish and parts of amphipod and isopod crustaceans (Zino et al., 1989). No plastic or other synthetic substances have been found in regurgitations. Petrels are also known to vary in their breeding success for no apparent reason (Warham, 1990).

One breeding bird has been captured in its burrow for over 10 years. If we assume that breeding could start when the bird was 6 years-of-age (cf. Simons, 1984), then this bird could be at least 16 -year-old. To date, no birds ringed as juveniles have been found breeding. This may be caused by the fact that they breed later than the estimated 6 years-of-age, or that we are unable to check on sufficient numbers of breeding adults on the study ledges. An alternative explanation is that there may be unexplored breeding ledges. One factor suggesting that new birds may have entered the breeding population is the reoccupation of a previously abandoned ledge and 
the recent discovery of two new nests on the known breeding areas. Artificial nest burrows, as used on the cahow, or boxes, as used with Gould's petrel, have been considered, but there are still vacant sites on the breeding ledges and it seems unnecessary to cause further disturbance. It is hoped that reducing the number of predators in the breeding area will make the ledges more attractive to potential breeders.

\section{Rat control}

The reduction in bait uptake between 1989 and 1995 is thought to represent a true decline in rat population caused by the action of rodenticide. This conclusion is supported by anecdotal evidence of the reduction in numbers of rat faeces on the Zino's petrel breeding ledges and additional snap trapping. Alternative explanations might include the development of behavioural resistance towards poison baits such as has been demonstrated in brown rats Rattus norvegicus (Brunton et al., 1993). Social transmission of aversion behaviour is thought unlikely because brodifacoum is a chronic poison (Buckle \& Smith, 1994), which has been successfully used in many other programmes (cf. Moors et al., 1992; Robertson et al., 1998; Innes et al., 1999).

Although levels of bait uptake in 1997 were still below 1989 levels, they had increased since 1996. Acquired resistance could explain this; low-grade physiological resistance to brodifacoum has been recorded in long-term campaigns against brown rats (Meehan, 1984; Greaves, 1985; Gill et al., 1992), but resistance in black rats is unknown. The change is taken, therefore, to represent circumstantial evidence of a recent increase in rat activity or population. The overall pattern of bait uptake between 1989 and 1997 suggests that although the rat population is limited by poisoning, it may be overlain by a natural cycle (Wood \& Liau, 1984). To obtain information about cyclic changes in rat population, a programme of population density measurements, independent of the bait uptake measurements, was begun in 1999 at three sites around the Zino's petrel breeding area. Sites were chosen to represent a range of habitats and to identify potential sources of immigrant rats, such as the upper limits of the laurel forest.

The effects of the overall decline in the rat population on Zino's petrel productivity are unclear. No significant relationship has been demonstrated and bait uptake data are unavailable for the early years of the project when rat activity is assumed to have been at its highest and petrel productivity at its lowest. In similar projects elsewhere, rat control has been critical to the recovery of petrel populations (cf. Cruz \& Cruz, 1987). As Zino's petrel productivity has occasionally dipped below the theoretical minimum for population stability, and consistent rat predation on small populations of burrownesting birds can be the determining factor in a decline to extinction (Cruz \& Cruz, 1987), we consider it vital to continue the poison-baiting programme.

The seasonal increase in bait uptake may reflect an increase in rat numbers caused by a small resident population reproducing between July and September, immigration of rats from other areas or a seasonal change in feeding behaviour. We suspect a combination of all three factors.

Black rat breeding ecology has not been fully investigated in Madeira. Evidence from live trapping at similar altitudes in Madeira suggests that rat breeding is seasonal (E. Easby, unpublished data). In other temperate areas, rodent breeding ecology can be related to patterns of rainfall and subsequent periods of increased plant growth (Clark, 1980; King, 1983). There may be increased reliance on bait as the seasonal food supply declines. Rats are opportunistic feeders and the seasonal maxima of bait uptake coincide with the Zino's petrel breeding season, therefore, control is particularly important from March to November. Consequently, it may be best in future years to reduce baiting and monitoring effort from December through to the end of February. This would reduce human effort during the winter months, when access to the area can be very difficult because of adverse weather conditions. Baiting should not cease completely because the laurel forest below the breeding area contains a permanent population of black rats, which require control throughout the year.

The location of the most active bait boxes suggests that rats may immigrate into the mountains via particular routes. If such 'corridors' to the Zino's petrel breeding area can be identified, additional baiting effort could be made in these areas together with the implementation of complementary measures such as trapping.

Both baiting and trapping are labour intensive. For this reason, further analyses should be undertaken to try to clarify the biotic and abiotic factors that make the location of bait boxes and traps most effective. In the meantime, it is recommended that current bait box locations remain the same.

\section{Cat control}

Although it was known that the mountains of Madeira had a high density of feral cats, it was thought that they would be unable to reach the breeding ledges. This was proved wrong on the 1987 Ledge. Moreover, some petrels have been observed on the ground, away from the ledges, in areas easily accessible to cats. Cats may represent a greater potential problem than rats because predation of adults birds represents a more 
serious threat to population viability than mortality of nestlings (Simons, 1984). The number of cats caught each year suggests that removal is compensated by immigration, probably from the forest below the breeding area.

To make cat trapping more effective, further investigations on the species' ecology and biology are required. In the short term, we suggest expansion of the protected area to accommodate the cat's likely home range. Cats commonly range $5-10 \mathrm{~km}$ when foraging at night (B. Bell, pers. comm.) and so the operational trapping area would have to be extended greatly, paying special attention to likely locations of cats, such as around restaurants or picnic areas in the vicinity. The capture of live animals is labour intensive and alternative control methods should be studied.

\section{Control of sheep and goats}

The lack of breeding habitat is a potential limiting factor to the spread of the petrels. Habitat degradation caused by overgrazing is a serious problem around the breeding area and until all goats and sheep are removed, there can be no easy solution. The feasibility of removing goats and sheep depends on the purchase of the necessary land by the government. In this case the area would become a Strict Nature Reserve, managed to increase the area of petrel breeding habitat. Management would include monitoring changes in other mammal populations such as rats and rabbits, Oryctolagus cuniculus, after stock removal, because fluctuations in potential prey numbers may affect populations of predator species such as the cat (Courchamp et al., 1999). The removal of sheep and goats from the area could produce an indirect advantage in the control of cats and rabbits. Grass regeneration associated with the climatic factors, such as frequent mists, would produce an environment most unattractive to cats and, to a lesser extent, rabbits.

\section{Other considerations}

In the past, collectors have taken both eggs and adults of this endangered species (Zino \& Zino, 1986). It is felt that this threat is now under control. However, the potential disturbance caused by the development of ecotourism directed at the petrel is being carefully monitored. Human presence in this area may have to be limited in the future.

\section{Conclusion and perspectives for the future}

The Freira Conservation Project has attempted to conserve Zino's petrel by addressing some of the principal threats to the species. It has achieved a small but crucial degree of success. The overall situation is still critical and it is recommended that current population monitoring and predator control should continue, together with a search for new breeding ledges.

To understand fully the problems that the petrel may encounter, new initiatives are needed to study the bird's breeding biology and ecology. Passive Integrated Transponder (PIT) tagging of Fea's petrel is about to start and is to be used to provide data on the breeding biology. Passive Integrated Transponder tags are inert and can be incorporated into a bird ring. They give a reading when challenged, identifying the tag and thus the bird. By placing two 'challengers' in series at the entrance of the nesting burrow it is possible to monitor the movements of the birds in and out of their nests. It will thus be possible to monitor incubation periods and frequency of feeding using a noninvasive technique. This initial trial will act as a model for similar work on Zino's petrel. Other methods of monitoring the birds' nesting behaviour, such as infra-red video cameras in the nest chamber, are being investigated.

Finally the Freira Conservation Project regards the purchase of the breeding area as the single most important step that remains to be taken for the protection of this endangered species. Although the land is included in the area covered by the legal statute of the 'Parque Natural da Madeira', a government organization for the conservation of nature, it is still privately owned. This fact limits the intervention of the Madeiran authorities, making the SPA status difficult to uphold. Acquisition of the land would provide the opportunity for removal of all grazing stock from the area, and the chance for habitat restoration. If funds become available to bring this to fruition, it would indeed be a great step forward in protecting Europe's rarest breeding seabird and the exceptional ecosystem in which it survives.

\section{Acknowledgements}

We are greatly indebted to João Gouveia, who is crucial to the success of this project. He is a retired Forestry Warden with intimate knowledge of the area. On retirement he joined the FCP as their warden and has patrolled the area on a weekly basis ever since, regardless of the weather conditions. He is always available and willing to help.

Other people who were/are important and to whom we are very grateful are: Günther (Jerry) Maul, Paul (Alec) Zino, Andy Swash (ADAS), the brothers Mendes Moreira (especially Miguel), Edward (Ted) Gerrard, Isamberto Silva, Duarte Câmara, Donato Caires, Andrew Easby, Victor Garcia Matarranz, Martin Jones, Luis de Frutos and Rui Dantas.

For institutional, financial and logistic support we are indebted to: Zeneca Agrochemicals, Parque Natural da 
Madeira, Museu Municipal do Funchal (História Natural), Parque Ecológico do Funchal, Royal Society for the Protection of Birds, International Fund for Animal Welfare and Dorisol-Hotels and Resorts.

The patient support and work of Elizabeth (Buffy), Alexander and Francesca Zino, Luisa Jardim Fernandes, Sandra Vasconcelos and Maria Gouveia cannot be forgotten.

\section{References}

Aranda, Y., Criado, J., Orueta, J., Tapia, G. \& Gomes, T. (1992) Estudio y control de dos poblaciones de espécies alóctonas, rata Rattus rattus y conejo Oryctolagus cuniculus en las Islas Chafarinas. Caracterización de la vegetación y seguimento. ICONA, Madrid [in Spanish] (Unpublished).

Bertram, D. \& Nagorsen, D. (1995) Introduced rats Rattus spp. on the Queen Charlotte Islands: implications for seabird conservation. Canadian Field Naturalist, 10, 6-10.

Bourne, W. (1955) The birds of the Cape Verde Islands. Ibis, 97, 508-556.

Bourne, W. (1957) Additional notes on the birds of the Cape Verde Islands, with particular reference to Bulweria mollis and Fregata magnificens. Ibis, 99, 182-190.

Bourne, W. (1983) The soft-plumaged petrel, the gon-gon and the freira, Pterodroma mollis, P. feae, and P. madeira. Bulletin of the British Ornithological Club, 103, 52-58.

Brunton, C., Macdonald, D. \& Buckle, A. (1993) Behavioural resistance towards poison baits in brown rats Rattus norvegicus. Applied Animal Behaviour Science, 38, 159-174.

Buckle, A. \& Swash, A. (1987) Protecting the Freira (Pterodroma madeira) from Predation by Rrodents. Unpublished Report for the International Council for Bird Preservation, Cambridge, UK.

Buckle, A. \& Zino, F. (1989) Saving Europe's rarest bird. Roundel, 5, 112-116.

Buckle, A. \& Smith, R. (eds) (1994) Rodent Pests and their Control. CAB International, Oxford, UK.

Clark, D. (1980) Population ecology of black rats Rattus rattus across a desert-montane forest gradient in the Galapagos. Ecology, 61, 1422-1433.

Collar, N. \& Stuart, S. (1985) Threatened Birds of Africa and Related Islands. The ICBP/IUCN Red Data Book, Part 1, 3rd edn. ICBP/ IUCN, Cambridge, UK.

Collar, N., Crosby, M. \& Stattersfield, A. (1994) Birds to Watch 2: The World List of Threatened Birds. BirdLife Conservation Series no. 4. BirdLife International, Cambridge, UK.

Coulter, M., Beach, T., Cruz, F. \& Evans, D. (1982) The Galapagos dark-rumped petrel project 1982. Charles Darwin Research Station, Annual Report, 158-162.

Courchamp, F., Langlais, M. \& Sugihara, G. (1999) Control of rabbits to protect island birds from cat predation. Biological Conservation, 89, 219-225.

Cruz, F. \& Cruz, J. (1987) Control of black rats and its effect on nesting dark-rumped petrels in the Galapagos Islands. Vida Silvestre Neotropical, 1, 3-13.

Gill, J., Kerrins, G. \& Macnicoll, A. (1992) Inheritance of low grade brodifacoum resistance in the Norway rat. Journal of Wildlife Management, 56, 809-816.
Grant, P. (1998) Patterns on islands and microevolution. In Evolution on Islands (ed. P. Grant), pp. 1-18. Oxford University Press, Oxford.

Greaves, J. (1985) The present status of resistance to anticoagulants. Acta Zoologica Fennica, 173, 159-162.

Groombridge, B. (1993) 1994 IUCN Red List of Threatened Animals. IUCN, Cambridge, UK.

Imber, M. (1985) Origins, phylogeny and taxonomy of the gadfly petrels Pterodroma spp. Ibis, 127, 197-229.

Innes, J., Hay, R., Flux, I., Bradfield, P., Speed, H. \& Jansen, P. (1999) Successful recovery of North Island kokako Callaeas cinerea wilsoni populations by adaptive management. Biological Conservation, 87, 201-214.

King, C.M. (1983) The relationship between beech (Nothofagus sp.) seedfall and populations of mice (Mus musculus) and the demographic and dietary responses of stoats (Mustela erminea) in three New Zealand forests. Journal of Animal Ecology, 52, 141-166.

Mathews, G. (1934a) Remarks on the races of Pterodroma mollis. Bulletin of the British Ornithological Club, 54, 178-179.

Mathews, G. (1934b) A check-list of the order Procellariiformes. Novitates Zoologicae, 39, 151-206.

Meehan, P. (1984) Rats and Mice: Their Biology and Control. Rentokil Ltd., East Grinstead.

Monaghan, P. (1995) Threats to seabirds: potential versus actual. In Threats to Seabirds: Proceedings of the 5 th International Seabird Group Conference (ed. M. Tasker). Seabird Group, Sandy, UK.

Moors, P., Atkinson, A. \& Sherley, G. (1992) Reducing the rat threat to island birds. Bird Conservation International, 2, 93-114.

Nunn, G. \& Zino, F. A molecular genetic diagnosis of the endangered Pterodroma gadfly-petrels nesting in the Madeiran Archipelago. Ibis. (submitted)

Quammen, D. (1997) The Song of the Dodo: Island Biogeography in an Age of Extinctions. Pimlico, London.

Robertson, H., Saul, E. \& Tira, A. (1998) Rat control in Rarotonga: some lessons for Mainland Islands in New Zealand. Ecological Management, 6, 1-12.

Salvadori, T. (1899) Cooezioni Ornitologiche Fatte nelle Isole del Capo Verde da Leonardo Fea. Annali del Museu Civico di Storia Naturale (Genova), 20, 283-312.

Schmitz, E. (1905) Tagebuch-Notizen aus Madeira. Ornithologisches Jahrbuch, 16, 219-226.

Simons, T. (1984) A population model of the endangered Hawaiian dark-rumped petrel. Journal of Wildlife Management, 48, 1065-1076.

Taylor, R. \& Thomas, B. (1993) Rat eradicated from rugged Breaksea Island (170 ha), Fiordland, New Zealand. Biological Conservation, 65, 191-198.

Warham, J. (1990) The Petrels: Their Ecology and Breeding Systems. Academic Press, London.

Wood, B. \& Liau, S. (1984) A long-term study of Rattus tiomanicus populations in an oil palm plantation in Johore, Malaysia. III: bionomics and natural regulation. Journal of Applied Ecology, 21, 473-495.

Zino, F. (1991) The Madeira Freira Conservation Project. World Birdwatch, 13, 8-9.

Zino, F. (1992) Cats amongst the freiras. Oryx, 26, 174.

Zino, F. \& Biscoito, M. (1994) Breeding seabirds in the Madeira archipelago. In Seabirds on Islands: Threats, Case Studies and 
Action Plans (eds D. N. Nettleship, J. Burger \& M. Gochfeld), pp. 172-185. BirdLife International, Cambridge, UK.

Zino, F., Biscoito, M. \& Neves, H.C. (1989) Madeira Freira Project. A confidential report, circulated to active partners in the project. Unpublished report, Freira Conservation Project, Madeira.

Zino, F., Biscoito, M. \& Zino, P. (1994) Zino's Petrel, Pterodroma madeira. In Birds in Europe: Their Conservation Status (eds G. Tucker \& M. Heath), pp. 62-63. BirdLife International, Cambridge, UK.

Zino, F., Heredia, B. \& Biscoito, M. (1996) Action Plan for Zino's Petrel (Pterodroma madeira). In Globally Threatened Birds in Europe. Action Plans (eds B. Heredia, L. Rose \& M. Painter), pp. 33-39. Council of Europe Publishing, Strasbourg.

Zino, P. \& Zino, F. (1986) Contribution to the study of the petrels of the genus Pterodroma in the archipelago of Madeira. Boletim do Museu Municipal do Funchal, 38, 141-165.

\section{Biographical sketch}

The authors of this paper are all connected with the Freira Conservation Project (FCP), set up in 1986 when it was noted that there was no successful breeding of Zino's Petrel on the known breeding ledges. The founder members were the Museu Municipal do Funchal (MMF) (Dr Manuel Biscoito), The Parque Natural da Madeira (Eng. Henrique Costa Neves), ICI (represented by Dr. Alan Buckle now with Syngenta AG), MAFF, and ICBP (represented by Dr. Francis Zino). The FCP is now coordinated by Dr. Francis Zino. Dr Sue King has had a long association with the project, working on rats and the flora. 